\title{
Production of dry fermented fish sausages by using different fish species and determination of the microbiological qualities
}

\section{Farklı balık türleri kullanarak fermente balık sucuklarının üretimi ve mikrobiyal kalitelerinin belirlenmesi}

\author{
Berna Kılınç ${ }^{\text {* }}$ • Şükran Çaklı² \\ ${ }^{1}$ Ege University, Fisheries Faculty, Fish Processing Technology Department, Bornova-İzmir, Turkey \\ ${ }^{2}$ Ege University, Fisheries Faculty, Fish Processing Technology Department, Bornova-Izmir, Turkey \\ https://orcid.org/0000-0002-4663-5082 \\ iD https://orcid.org/0000-0002-2419-9064
}

\section{How to cite this paper:}

KIIInç, B. \& ÇaklI, Ş. (2021). Production of dry fermented fish sausages by using different fish species and determination of the microbiological qualities. Ege Journal of Fisheries and Aquatic Sciences, 38(3), 329-336. DOI:10.12714/egejfas.38.3.09

Abstract: In this study frozen-thawed rainbow trout (Onchorhynchus mykiss) and seabass (Dicentrarchus labrax) fillets were used for preparing of dry fermented fish sausages. The total mesophilic aerob bacteria (TMAB), total psychrophilic aerob bacteria (TPAB), yeast-mould (YM), lactic acid bacteria (LB), Enterobactericeae (EB), Staphylococcus aureus (SA) changes of these dry fermented sausages were examined in the refrigerated storage at $6-8^{\circ} \mathrm{C}$. At the end of the storage period of 90 days, the results of the TMAB, TPAB, YM, LB, EB and SA counts of dry fermented seabass sausages were determined as $6.25,7.01,3.61,5.31,<1.0$ ve $<1.0 \mathrm{log}$ cfu/g, while, TMAB, TPAB, YM, LB, EB and SA counts of dry fermented trout sausages were found as 6.57, 7.20, $4.44,5.14,<1.0$ ve $<1.0 \mathrm{log}$ cfu/g, respectively. In this study both fermented fish sausages were determined as too much dried and exceeded the microbiological limit of TMAB at the end of the storage period of 90 days in the refrigerator. However, fermented seabass sausage reached the maximum level of YM count on the $10^{\text {th }}$ day of storage, whereas fermented trout sausage reached this level on the $30^{\text {th }}$ day of storage. Therefore, it is suggested that they should be packaged in vacuum packaging because of preventing too much drying and the growth of undesirable moulds. Additionally, the identification of microorganisms in fermented fish sausages would also be advised to determine desirable and undesirable microorganisms. Dry fermented fish sausage would be an alternative product to traditional dry fermented meat sausage in Turkey because of the health benefits of fish.

Keywords: Fish species, dry fermented fish sausage, microbiological quality

Öz: Bu çalışmada dondurulmuș çözündürülmüs alabalık (Onchorhynchus mykiss) ve levrek (Dicentrarchus labrax) filetoları kullanılarak balık sucukları üretilmiş̧tir. 6-8 $8^{\circ} \mathrm{C}$ 'de buzdolabında depolanan alabalık ve levrek sucuklarının toplam mezofil aerob bakteri (TMAB), toplam psikrofil aerob bakteri (TPAB), maya-küf (MK), laktik asit bakteri (LB), Enterobactericeae (EB) ve Staphylococcus aureus (SA) değişimleri incelenmiştir. Depolamanın 90. gününde fermente levrek sucuklarını TMAB, TPAB, MK, LB, EB ve SA bakteri sayıları sırasıyla 6,$25 ; 7,01 ; 3,61 ; 5,31 ;<1,0$ ve $<1,0$ log kob/g olarak tespit edilirken, alabalıktan üretilen fermente balık sucuklarının TMAB, TPAB, MK, LB, EB ve SA bakteri sayıları sırasıly 6,$57 ; 7,20 ; 4,44 ; 5,14 ;<1,0$ ve $<1,0 \log$ kob/g olarak saptanmıştır. Çalışmada her iki fermente balık sucuğunun da buzdolabında 90 günlük depolama periyodu sonunda çok fazla kurudukları ve TMAB açısından mikrobiyolojik limit değerini geçtikleri saptanmıştır. Buna karşın, en yüksek MK değerlerine levrek sucukları depolamanın 10. gününde ulaşırken, alabalık sucukları depolamanın 30. gününde ulaşmış̧ır. Bu nedenle depolama esnasında çok fazla kurumanın ve istenmeyen küf gelişiminin önlenmesi için fermente balık sucuklarııın vakum paketleme kullanılarak paketlenmesi önerilir. Ayrıca fermente balık sucuklarında mikroorganizmaların tanımlanması da arzu edilen ve istenmeyen mikroorganizmaların belirlenmesi için tavsiye edilir. Türkiye'de balık sucukları sağlığa yararlı olmaları nedeniyle geleneksel etten üretilen sucukların yerine alternatif olabilir.

Anahtar kelimeler: Balık türleri, fermente balık sucuk, mikrobiyal kalite

\section{INTRODUCTION}

The improvement of safety and standardization of fermented meat products with the typical characteristics is very essential and can be achieved naturally or sometimes by using native starter cultures that influence appearance, colour, odour, flavor and texture of these products (Cruxen et al., 2019). The most important part of these fermented meat products are fermented fish products (Kılınç et al., 2006) that they have been also produced and consumed in some parts of the world (Kılınç, 2003; Kılınç, 2004). In many parts of the world fermented sausages are traditional products that they have been consumed by most of the consumers for centuries (Bou et al., 2017). Additionally, the process of the manufacture of these fermented meats is a very important part of the meat industry in many countries (Fernandez et al.,
2000). The raw materials of the manufacture of fermented sausage are derived from variety of meats and fat tissue. Nonmeat ingredients such as water, salt, spices, sugars, ascorbates and phosphates have been also used for the manufacturing of sausages to improve the flavor and taste characteristics of sausages (Lonergan et al., 2019). The qualities of dry fermented products depend on many factors such as the microbial microflora, the chemico-physical variables and the hygienic procedure of these products during processing stage etc. (Suzzi and Gardini, 2003). Many dry fermented products have been produced in different formulation in the many parts of the world (Incze, 1998; KIlınç, 2004; Papamanoli et al., 2003; Nordvi et al., 2007; Ordonez et al., 2010; Vignolo et al., 2010; Papavergou, 2011; Khem et 
al., 2013; Holck et al., 2017; Sidira et al., 2019; GonzalezMohino et al., 2020). Sucuk is one of the most important dry fermented meat product of Turkey. In Turkey, this product has been frequently produced from beef or lamb by adding spices, salt, and tail fat into these meats (Kaban and Kaya, 2006). Then prepared sucuk dough has been filled into casings before fermentation process, which occured under uncontrolled conditions (Bozkurt and Bayram, 2006). Fermentation could be formed by the natural microbial flora of sucuk (Kaya and Gökalp, 2004). The microflora of fermented products commonly have been consisted of lactic acid bacteria, coagulase negative coccus, enterococcus, and yeasts (Rantsiou and Cocolin, 2006). The lactic acid bacteria counts of fermented sucuks generally have been changed from $10^{2}$ to $10^{4} \mathrm{cfu} / \mathrm{g}$. However, these values were reported by Apaydın et al. (2009) could be risen during the process of fermentation. The microorganisms, which were responsible for the process of fermentation, notified by Kaya and Gökalp (2004) that were Kocuria, Staphylococcus, Lactobacillus and Pediococcus. According to Turkish Standards Institution; Lactobacillus (L. plantarum, L. pentosus, L. curvatus, L. sake), Pediocoocus (P. pentosaceus, $P$. acidilactici, Micrococcus (Korucia varians) and Debaryomyces (D. hansenii) have been used as the starter cultures for the production of sucuks (TSE, 2002). Con and Gökalp (2000) informed that the group of lactic acid bacteria were not only responsible for the process of fermentation, but also they could be inhibited spoilage and pathogenic bacteria during fermentation process. In recent years heat treatments have been applied on sucuks in terms of inhibiting the harmful microbial flora of sucuks. But, these heat treatments had bad effects on the formation of flavours described by Ercoşkun, (2006). Spices and ingredients, which have been added into sucuks, improved the flavour and colour characteristics of sucuks (Bozkurt and Erkmen, 2007). Sucuk has been produced through microbial fermentation and drying process (Aksu and Kaya, 2004). When looking at the literatures; many studies have been done about dry fermented meat products which have been produced from beef, sheep, goat, buffalo, camel etc. (Bozkurt and Erkmen 2002; Suzzi and Gardini, 2003; Kara et al., 2012; Atik, 2013; Yoo et al. 2016; Cunha et al., 2018; Adab et al., 2020). Many studies also have been done about dry fermented fish sausauges (Khem et al., 2013; Stollewerk et al. 2014; Wang et al., 2017) in the world. In addition to this, some studies have been done about fish sausages (Dinçer et al., 2007a, Dinçer et al. 2007b; Özpolat, 2012; Dinçer and Çaklı, 2015; Dinçer et al., 2017; Çoban, 2020), fish jambon (Eren, 2011) and shark meat sausage (YIlmaz and Berik, 2013), whereas limited studies have been done about dry fermented fish sausages (Arslan et al., 2001; Berik and Kahraman, 2010) in Turkey.

Fish compounds were beneficial to health. However, many people prefer to eat little or no fish. Therefore, the development of convenient and new fish products, which were easy to eat to increase the fish intake, was necessary reported by Nordvi et al. (2007). In addition to this; there have been no production and consumption of dry fermented fish sausages which are made from fish species in Turkey. For this reason; the aim of this study was to produce dry fermented fish products from sea bass and rainbow trout. And also microbiological changes of these dry fermented fish sausages were determined during storage period.

\section{MATERIAL AND METHODS}

\section{Material and the preparation of fermented fish sausages}

In this study frozen at $-18^{\circ} \mathrm{C}$ for 3 months and then thawed rainbow trout (Onchorhynchus mykiss) and seabass (Dicentrarchus labrax) fillets were used. The preparation of dry fermented fish sausage is shown in Figure 1. Dry fermented fish sausages were prepared by using fish, beef tail fat, salt, garlic, red pepper, hot red pepper, black pepper, ginger, cinnamon, cumin, sucrose, allspice and potassium sorbate. All spices, which were sold as open, were bought from the spice shop in the Bornova province of Turkey. All formulations contain $1200 \mathrm{~g}$ fish meat, $75 \mathrm{~g}$ beef tail fat, $20 \mathrm{~g}$ salt, $41.0 \mathrm{~g}$ garlic, $30.3 \mathrm{~g}$ red pepper, $20.3 \mathrm{~g}$ hot red pepper, $9.4 \mathrm{~g}$ black pepper, $7.25 \mathrm{~g}$ ginger, $7.0 \mathrm{~g}$ cinnamon, $9.3 \mathrm{~g}$ cumin, $7.3 \mathrm{~g}$ sucrose, $3.72 \mathrm{~g}$ allspice, $\% 0.03$ potassium sorbate in their recipe. After the fish meat was homogenized by using the blender, all spices were added and then they were mixed for 10 minutes. After leaving the mixture in the refrigerator (at $\left.6-8{ }^{\circ} \mathrm{C}\right)$ overnight, the sausage filling machine (Sfinx, Czech Republic) were used to be stuffed this mixture into the natural casings to be about approximatelly $10 \mathrm{~cm}$ and the end parts were tied with rope and cut. Prepared rainbow trout and seabass sausages were put into refrigerator at 6-8 ${ }^{\circ} \mathrm{C}$ and the microbiological changes were examined during storage period.

\section{Material of dry fermented fish sausages}

Frozen-thawed (at $-18^{\circ} \mathrm{C}$ for 3 months) Rainbow trout and seabass fillets

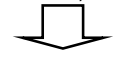

Dry fermented fish sausages preparation

Fish fillets were minced and mixedwith spices (salt, garlic, red, hot red,black pepper, ginger, cinnamon, cumin,sucrose, allspice, tail fat and potassium sorbate)
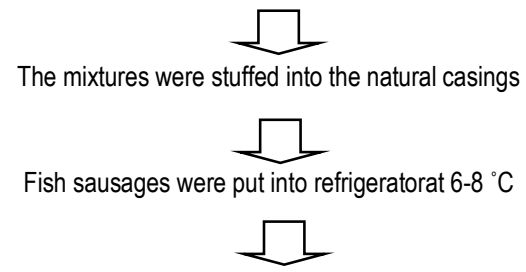

The microbiological changes of dry fermented fishsausages were determined during storage period

Figure 1. The preparation of dry fermented fish sausages 


\section{Microbiological analyses}

\section{Sampling for microbiological analyses}

Three dry fermented fish sausages of each type were removed in the $1^{\text {st }}, 5^{\text {th }}, 10^{\text {th }}$ and $15^{\text {th }}, 30^{\text {th }}, 60^{\text {th }}$ and $90^{\text {th }}$ day of storage period. $10 \mathrm{~g}$ of samples was removed from each dry fermented fish sausage and homogenized in a stomacher (IUL, Barcelona, Spain) containing $90 \mathrm{ml}$ of $0.1 \%$ peptone water (Difco, 0118-17-0). Other serial dilutions were prepared from this solution. Double trial for each dilution were tested.

\section{Microbiological methods}

The TMAB counts of dry fermented sausages were done according to method of (ICMSF, 1983). The Pour Plate Method was used for determining TMAB and TPAB counts of dry fermented fish sausages. One mililiter of inoculum were put into the petridishes and then Plate Count Agar (PCA, Oxoid, CM0325) was poured onto the inoculum. Inoculated petri dishes were incubated for $48 \mathrm{hrs}$ at $30^{\circ} \mathrm{C}$ for the TMAB analysis. After incubation, colonies on petridishes were enumerated and converted into log cfu/g. The TPAB counts were determined according to method of (Merck, 1998). Plate Count Agar (PCA, Oxoid, CM0325) was also used for the TPAB count as the medium. One mililiter of inoculum was taken from each dilution and then put onto the petri dishes. Then approximately $15-20 \mathrm{ml}$ of Plate Count Agar (PCA, Oxoid, CM0325) was poured onto the each inoculum. Inoculated petri dishes were incubated for 14 days at $4^{\circ} \mathrm{C}$ for the TPAB analysis. Colonies were enumerated as the TPAB counts and converted into log cfu/g. The LB counts of dry fermented fish sausages were done according to method of (DeMan et al., 1960). Double layer plate method was used for the determination of the LB counts of samples. One mililiter of inoculum was put into the petridishes and then Man Rogosa Sharpe Agar (MRSA) (LABM 93) was poured onto the inoculum as double layer. Inoculated petri dishes were incubated for 5 days at $30^{\circ} \mathrm{C}$ for determining the LB counts of samples. Colonies were enumerated after the incubation as the LB. For the YM counts; Qxytetracycline Yeast Extract Agar (LABM $\mathrm{X} 89$ ) was used as medium and the incubation period was for $3-5$ days at $30^{\circ} \mathrm{C}$. The $\mathrm{YM}$ counts were done according to method of (Harrigan and McCance, 1976) by using the Pour Plate method. The Enterobacteriaceae counts of dry fermented sausages were done according to method of (Vanderzant and Splittstoesser, 1992). Violet Red Bile Dextrose Agar (VRBD, Merck, 1.10275.0500) was used as medium for the EB counts. The inoculation was done by using the double layer plate method. After inoculation, incubation was done for $24 \mathrm{hrs}$ at $37^{\circ} \mathrm{C}$. The Staphylococcus bacteria counts were done according to method of (Mossel and Moreno-Garcia, 1985). For the SA counts of dry fermented sausages, Baird Parker Agar (BPA, Merck, 1.05406.0500) was used as medium and the egg yolk tellurite emulsion (Merck, 103785) was used as supplement. After inoculation, inoculated petri dishes were incubated for $30 \mathrm{hrs}$ at $37^{\circ} \mathrm{C}$ (Mossel and Moreno-Garcia, 1985). All microbiological analyses were done triplicate.

\section{Statistical analysis}

Statistical analysis was performed by using the Statistical Program for Social Sciences (SPSS ver. 25.0). The effect of storage periods on to the groups were analyzed. KruskalWallis and Mann-Whitney tests were used for determining the differences of bacteria counts between the groups (Gamgam and Altunkaynak, 2017). The level of significance was indicated as $p<0.05$ and the level of not significance was as $p>0.05$.

\section{RESULTS AND DISCUSSION}

The microbiological quality of fermented seabass sausage are shown in Table 1. At the beginning of fermentation process; TMAB, TPAB, YM, LB, EB and SA counts of fermented seabass sausages were determined as 2.49, 2.41, $1.15,2.02,2.09,<1.0 \log \mathrm{cfu} / \mathrm{g}$, while at the end of the storage period of 90 days, the results of the mesophilic, TMAB, TPAB, YM, LB, EB and SA counts of fermented seabass sausage were determined as $6.25,7.01,3.61,5.31,<1.0$ ve $<1.0$ log cfu/g, respectively.

Table 1. The results of the microbiological counts of dry fermented seabass sausage during storage period

\begin{tabular}{|c|c|c|c|c|c|c|}
\hline \multirow[b]{2}{*}{ Day } & \multicolumn{5}{|c|}{ Microbiological analyses of dry fermented seabass sausage } & \multirow[b]{2}{*}{$\begin{array}{c}\text { SA } \\
(\log c f u / g)\end{array}$} \\
\hline & $\begin{array}{c}\text { TMAB } \\
(\log c f u / g)\end{array}$ & $\begin{array}{c}\text { TPAB } \\
(\log c f u / g)\end{array}$ & $\begin{array}{c}\text { YM } \\
\text { (log cfu/g) }\end{array}$ & $\begin{array}{c}\text { LB } \\
(\log c f u / g)\end{array}$ & $\begin{array}{c}\text { EB } \\
(\log c f u / g)\end{array}$ & \\
\hline 1 & $2.49 \pm 0.14^{a}$ & $2.41 \pm 0.18^{a}$ & $1.15 \pm 0.21^{a}$ & $2.02 \pm 0.03$ a & $2.09 \pm 0.13^{a}$ & $<1.0^{a}$ \\
\hline 5 & $3.91 \pm 0.07$ b & $3.83 \pm 0.03^{b}$ & $1.81 \pm 0.04 b$ & $2.26 \pm 0.01 b$ & $1.85 \pm 0.05^{b}$ & $<1.0^{a}$ \\
\hline 10 & $4.31 \pm 0.18^{c}$ & $4.60 \pm 0.19 c$ & $2.02 \pm 0.09 \mathrm{c}$ & $3.35 \pm 0.05^{c}$ & $<1.0^{c}$ & $<1.0^{a}$ \\
\hline 15 & $4.85 \pm 0.09 \mathrm{~d}$ & $4.93 \pm 0.05^{d}$ & $2.21 \pm 0.05 \mathrm{~cd}$ & $4.02 \pm 0.03^{d}$ & $<1.0^{c}$ & $<1.0^{a}$ \\
\hline 30 & $5.37 \pm 0.29$ e & $5.52 \pm 0.15^{\mathrm{e}}$ & $2.34 \pm 0.06 \mathrm{de}$ & $4.49 \pm 0.13 \mathrm{e}$ & $<1.0^{c}$ & $<1.0^{a}$ \\
\hline 60 & $5.43 \pm 0.10 \mathrm{e}$ & $5.67 \pm 0.07 \mathrm{e}$ & $2.44 \pm 0.11 \mathrm{e}$ & $4.75 \pm 0.07^{f}$ & $<1.0^{c}$ & $<1.0^{a}$ \\
\hline 90 & $6.25 \pm 0.37^{f}$ & $7.01 \pm 0.19^{f}$ & $3.61 \pm 0.11^{f}$ & $5.31 \pm 0.06 \mathrm{~g}$ & $<1.0^{c}$ & $<1.0^{a}$ \\
\hline \multicolumn{7}{|c|}{$\begin{array}{l}\mathrm{n}=3 \text { (Mean value } \pm \text { Standard deviation), the mean value within each column with different small letters are statistically different }(p<0.05) \text { according to } \\
\text { storage period. TMAB: Total mesophilic aerob bacteria, TPAB: Total psychrophilic aerob bacteria, MY: Yeast-Mould, LB: Lactic acid bacteria } \\
\text { EB: Enterobactericeae, SA: Staphylococcus aureus }\end{array}$} \\
\hline
\end{tabular}


The microbiological quality of dry fermented trout sausage are given in Table 2. At the beginning of fermentation process; TMAB, TPAB, YM, LB, EB and SA counts of fermented trout sausage were found as $2.47,2.35,1.00,1.95$,
1.24 and $<1.0 \log \mathrm{cfu} / \mathrm{g}$, while at the end of the storage period of 90 days; TMAB, TPAB, YM, LB, EB and SA counts of fermented trout sausage were found as $6.57,7.20,4.44,5.14$, $<1.0$ ve $<1.0 \log \mathrm{cfu} / \mathrm{g}$, respectively.

Table 2. The results of the microbiological counts of dry fermented trout sausage during storage period

\begin{tabular}{|c|c|c|c|c|c|c|}
\hline \multicolumn{7}{|c|}{ Microbiological analyses of dry fermented trout sausage } \\
\hline Day & $\begin{array}{c}\text { TMAB } \\
(\log c f u / g)\end{array}$ & $\begin{array}{c}\text { TPAB } \\
(\log c f u / g)\end{array}$ & $\begin{array}{c}\mathrm{YM} \\
(\log c f u / g)\end{array}$ & $\begin{array}{c}\text { LB } \\
(\log c f u / g)\end{array}$ & $\begin{array}{c}\text { EB } \\
\text { (log cfu/g) }\end{array}$ & $\begin{array}{c}\text { SA } \\
\text { (log cfu/g) }\end{array}$ \\
\hline 1 & $2.47 \pm 0.07^{\mathrm{a}}$ & $2.35 \pm 0.06^{a}$ & $1.00 \pm 0.00^{a}$ & $1.95 \pm 0.07$ a & $1.24 \pm 0.34$ a & $<1.0^{a}$ \\
\hline 5 & $3.82 \pm 0.18^{b}$ & $3.83 \pm 0.02^{b}$ & $1.59 \pm 0.16^{b}$ & $2.32 \pm 0.19 b$ & $1.15 \pm 0.21 b$ & $<1.0^{a}$ \\
\hline 10 & $4.34 \pm 0.19 c$ & $4.37 \pm 0.17 c$ & $1.88 \pm 0.04 c$ & $3.90 \pm 0.07 c$ & $<1.0^{\circ}$ & $<1.0^{a}$ \\
\hline 15 & $4.91 \pm 0.06^{\mathrm{d}}$ & $4.96 \pm 0.01 \mathrm{~d}$ & $1.93 \pm 0.04^{\mathrm{cd}}$ & $4.21 \pm 0.06^{d}$ & $<1.0 c$ & $<1.0^{a}$ \\
\hline 30 & $5.01 \pm 0.05^{\mathrm{e}}$ & $5.04 \pm 0.06^{\mathrm{e}}$ & $2.11 \pm 0.09 \mathrm{de}$ & $4.42 \pm 0.17^{\mathrm{e}}$ & $<1.0^{c}$ & $<1.0^{a}$ \\
\hline 60 & $5.02 \pm 0.09 \mathrm{e}$ & $5.29 \pm 0.81 \mathrm{e}$ & $2.25 \pm 0.07 \mathrm{e}$ & $4.55 \pm 0.07^{f}$ & $<1.0^{c}$ & $<1.0^{a}$ \\
\hline 90 & $6.57 \pm 0.08^{f}$ & $7.20 \pm 0.14^{f}$ & $4.44 \pm 0.33^{f}$ & $5.14 \pm 0.10 \mathrm{~g}$ & $<1.0^{\circ}$ & $<1.0^{a}$ \\
\hline
\end{tabular}

$\mathrm{n}=3$ (Mean value \pm Standard deviation), the mean value within each column with different small letters are statistically different $(\mathrm{p}<0.05)$ according to storage period. TMAB: Total mesophilic aerob bacteria, TPAC: Total psychrophilic aerob bacteria, YM: Yeast-mould, LB: Lactic acid bacteria, EB: Enterobactericeae, SA: Staphylococcus aureus

TMAB, TPAB, YM, LB counts of fermented seabass and trout sausages were increased during storage period. Significant differences $(p<0.05)$ were determined in microrganism counts during storage, but not significant differences $(p>0.05)$ were determined in microorganism counts between the groups according to time of storage. TMAB counts of dry fermented seabass and trout sausages were determined as 2.49 and $2.47 \mathrm{log}$ cfu/g on the first day of storage. After 90 days of storage period, TMAB counts of fermented seabass and trout sausages increased to 6.25 and $6.57 \mathrm{log}$ cfu/g, respectively.

TPAB counts of fermented seabass sausage increased from 2.41 to $7.01 \mathrm{log}$ cfu/g, while TPAB counts of fermented trout sausages increased from 2.35 to $7.20 \mathrm{log} \mathrm{cfu} / \mathrm{g}$ at the end of the storage period. The initial YM counts of fermented seabass and trout sausages were found as 1.15 and $1.00 \mathrm{log}$ $\mathrm{cfu} / \mathrm{g}$., respectively. After 90 days of the storage, these values increased to $3.61 \mathrm{log}$ cfu/g for the fermented seabass sausage and $4.44 \log \mathrm{cfu} / \mathrm{g}$ for the fermented trout sausage. The LB counts of both fermented sausages increased during storage period. The LB counts of fermented seabass sausages were determined as $2.02,2.26,3.35,4.02,4.49$, $4.75,5.31 \mathrm{log}$ cfu/g on the $1^{\text {th }}, 5^{\text {th }}, 10^{\text {th }}, 15^{\text {th }}, 30^{\text {th }}, 60^{\text {th }}$ and $90^{\text {th }}$ day of storage period, respectively. The LB counts of fermented trout sausage increased from $1.95 \mathrm{log}$ cfu/g to 4.21 $\log \mathrm{cfu} / \mathrm{g}$ on the $15^{\text {th }}$ day of storage. During storage period the LB counts of fermented trout sausage found as $4.42,4.55$, $5.14 \log \mathrm{cfu} / \mathrm{g}$, on the $30^{\text {th }}, 60^{\text {th }}, 90^{\text {th }}$ day of storage, respectively. The EB counts of fermented seabass and trout sausages were determined as 2.09 and $1.24 \mathrm{log}$ cfu/g at the begining of the storage, respectively. However, this bacteria counts inhibited on both fermented sausages on the $10^{\text {th }}$ day of storage. The SA was not determined in any of fermented sausages during storage period.
According to the Kruskal Wallis test, there was no significant difference $(p>0.05)$ between the mean values of fermented seabass and trout sausages in terms of the TMAB counts ( $p$-value $=0.772$ ). However, the difference between days was statistically significant $(p<0.05)$ for both fish species in terms of the TMAB ( $p$-value $=0.000$ ). The Mann Whitney test was done for determining the differences between the days. The difference between the days was not significant ( $p$ value $=0.818$ ) on the $30^{\text {th }}$ and $60^{\text {th }}$ days of storage while the difference between all other days was statistically significant $(p<0.05)$ in both groups. There was no significant difference $(p>0.05)$ between the average values in terms of the TPAB counts of fermented seabass and trout sausages ( $p$ value $=0.792$ ). However, the difference between two fish species in terms of the days for the TPAB counts found to be statistically significant ( $p$-value $=0.000$ ). The Mann Whitney test was also done for determining the differences between the days. The difference between the days was not significant ( $p$-value $=0.132$ ) on the $30^{\text {th }}$ and $60^{\text {th }}$ days of storage, while the difference of the TPAB counts between all other days was statistically significant $(p<0.05)$ in both groups. According to the Kruskal Wallis test, there was no significant difference $(p>0.05)$ between the mean values of YM counts for fermented seabass and trout sausages ( $p$ value $=0.792$ ), but the difference between days for the two fish species was statistically significant ( $p$-value $=0.000$ ). The difference between the days was checked by using the Mann Whitney test. The difference between the days was not significant on the $10^{\text {th }}$ and $15^{\text {th }}$ days of storage was ( $p$-value $=0.180), 15^{\text {th }}$ and $30^{\text {th }}$ days of storage was $(p$-value $=0.180), 30^{\text {th }}$ and $60^{\text {th }}$ days of storage was $(p$-value $=0.180)$. However, the difference between all other days was found as statistically significant $(p<0.05)$. There was no significant difference between the mean value of of LB counts of fermented seabass and trout sausages ( $p$ value $=0.85$ ), but the difference between days was statistically significant $(p<0.05)$ for the both fish species $(p-v a l u e=0.000)$. 
The difference between all days was checked by using the Mann Whitney test. Statistically significant difference $(p<0.05)$ between all days were determined between the both groups.

The TMAB count was not only a good indicator for deciding the acceptability of fermented food products but also, it should be considered together with the number of LB of these products whether or not they were suitable for consumption (Ünlütürk and Turantaş, 2003). Ekici et al. (2015) reported that the TMAB counts of dry fermented sausages were determined as $\sim 8.5 \mathrm{log} \mathrm{cfu} / \mathrm{g}$. In another report, the TMAB in fermented sausages was reported to be between 6.00 and $7.00 \mathrm{log}$ cfu/g (Ekici and Omer, 2018). In our study, the TMAB counts of fermented seabass and trout sausages were determined as 6.25 and $6.57 \mathrm{log} \mathrm{cfu} / \mathrm{g}$ at the end of the storage period of 90 days. During storage period at 6-8 ${ }^{\circ} \mathrm{C}$, the TPAB counts of the both fermented fish sausages were determined higher than the TMAB counts of the fermented fish sausages after $5^{\text {th }}$ day of storage. The total number of TMAB in fermented sausages obtained under hygienic conditions should be below 6.0 log cfu/g (Öksüztepe et al., 2011). Both fermented seabass and trout sausages exceeded this limit $(6.0 \mathrm{log} \mathrm{cfu} / \mathrm{g})$ on the $90^{\text {th }}$ day of storage in our study.

Arslan and Soyer (2018) reported that sausages were exposed to the high humidity during the fermentation process, which could be caused the growth of both desirable and undesirable fungi on the surface of sausages. Furthermore, controlled molds growth was reported that they gave sausages a typical flavor as a result of degredation of lipids and proteins. However, uncontrolled mould growth was indicated that they could be responsible for the discoloration of the surface of sausages as well as spoilage. In our study, the YM counts of fermented sea bass sausage changed from 1.15 to $3.61 \mathrm{log} \mathrm{cfu} / \mathrm{g}$, while the YM counts of fermented trout sausages changed from 1.00 to $4.44 \mathrm{log}$ cfu/g after 90 days of storage. Arslan et al. (2001) found that the number of YM counts were determined increasing in all groups of fermented Cyprinus carpio sausages from 1 to $30^{\text {th }}$ day of storage. At the end of the $30^{\text {th }}$ day of storage; the YM counts of four different Cyprinus carpio sausages were found to be as 4.59, 4.88, 4.79 and $4.60 \log \mathrm{cfu} / \mathrm{g}$.

In this study the authors reported that the excessive number of the YM counts of fermented products could be due to the growing the ability of the YM in these type of products easily. Besides, the authors denoted that the fermented products could be contaminated with the food additives, particulary from the spices (Arslan et al., 2001). In another study; the YM counts of the traditional fermented sausages were described as varied from $3 \mathrm{log} \mathrm{cfu} / \mathrm{g}$ to $5 \mathrm{log} \mathrm{cfu} / \mathrm{g}$ (Erkmen and Bozkurt, 2004). Ekici et al. (2015) defined that exhibited significant variations among the YM counts of samples ranging from $3.54 \mathrm{log} \mathrm{cfu} / \mathrm{g}$ to $5.21 \mathrm{log} \mathrm{cfu} / \mathrm{g}$. The yeast and mould counts of Milano type of traditional fermented sausages were found as $4.2 \pm 0.08$ and $4.8 \pm 0.03$ log cfu/g, respectively (Haouet et al., 2017). In our study, the
YM count of the dry fermented seabass sausage increased to $3.61 \log \mathrm{cfu} / \mathrm{g}$, while the YM count of fermented trout sausage increased to $4.44 \mathrm{log} \mathrm{cfu} / \mathrm{g}$ at the end of the storage period. Our results were well accordance with the above studies (Arslan et al., 2001; Erkmen and Bozkurt, 2004; Ekici et al., 2015; Haouet et al., 2017) about the number of YM of fermented products.

According to Institute of Turkish Standards (2002), the maximum level of the YM counts of dry fermented meat product was defined as microbiologically to be $2.00 \mathrm{log} \mathrm{cfu} / \mathrm{g}$.

In the study, fermented seabass sausage reached this limit on the $10^{\text {th }}$ day of storage, whereas fermented trout sausage reached this limit on the $30^{\text {th }}$ day of storage. The high number of YM on dry fermented sausages could be from the spices that used in the study. For this reason, the authors thougt that the spices should be prefered at the best hygienic quality for producing dry fermented fish sausages. The LB counts of both fermented fish sausages increased during storage period. At the end of the storage period; the LB counts of fermented seabass sausage increased from 2.02 to $5.31 \mathrm{log}$ cfu/g while the LB counts of fermented trout sausages changed from 1.95 to $5.14 \log \mathrm{cfu} / \mathrm{g}$.

In one report; high number of LB in the fermented sausages was reported by the authors that this group of bacteria was to be the predominant flora of the fermented sausages (Arslan and Soyer, 2018). In another report; the LB counts of fermented sausages were reported to be responsible for the quality development of these products during processing as well as the qualities of fermented sausages could be affected by the LB during marketing (Yaman et al., 1998). Adab et al. (2018) reported that the acidifying activity of the LB that an important role in the stability of the dry fermented meat products, following the inhibition of the growth of the pathogenic and spoilage microorganisms. In our study, the results of the increasing of the LB counts in the dry fermented fish sausages were in agreement with those of (Yaman et al., 1998; Arslan and Soyer, 2018; Adab et al. 2018).

The authors revealed in one study that the addition of the spice, especially cinnamon into the dry fermented sausages was an advisable to improve the sensory quality and also the inhibition of the growth of Enterobacteriaceae (Sun et al., 2018). The result of our study was well correlated with this above study (Sun et al., 2018) about the inhibition of the growth of the EB in dry fermented fish sausages. The EB count of fermented sausages was a good indicator for the sanitary of the production conditions (Arslan and Soyer, 2018). In one report, the number of $E B$ species in the processing period of fermented meat products decreased due to the acidification. Moreover, fast acidification was resulted in a significant reduction in the number of this type of bacteria was reported by (Lücke, 1985). In another study, the authors also indicated that the EB count decreased during the production process of the fermented meat product (Kaban 
and Kaya, 2009). In our study, the EB count decreased in the both groups of the fermented fish sausages on the $5^{\text {th }}$ day of storage and then it was determined to be lower than the detection limit on the $10^{\text {th }}$ day of storage. Our results were determined well correlation with these above investigations (Lücke, 1985; Kaban and Kaya, 2009) about decreasing and inhibition of this type of microorganisms in dry fermented sausages.

Kaban and Kaya (2006) reported that $S$. aureus was an important foodborne pathogenic bacteria in fermented meat sausage. In one report the authors showed that pathogenic and spoilage bacteria could not grow in the finished fermented fish sausages because of good hygienic procedure of processing. In their study the authors determined the decreasing of bacteria during processing. Additionally, they reported that the pathogenic bacteria was not detected during storage (Stollewerk et al., 2014). Scetar et al. (2013) also reported that the good hygienic quality during the entire processing and storage as no pathogens were detected in their study. Similar results were observed in our study with these above studies that the SA was not detected in the both groups of fermented fish sausages during storage period in the refrigerator.

\section{CONCLUSION}

In conclusion, dry fermented fish sausage can be a healty alternative product to fermented meat products in Turkey because of health benefits of fish. In our study; we produced fermented fish sausages by using seabass and trout fillets in laboratory conditions. However, cheap, discarded and economical fish species can be evaluated for producing

\section{REFERENCES}

Adab, S.E., Zaghbib, I. Tekiki, A. \& Hassouna, M. (2018). Shelf-life determination of dry fermented poultry mest sausage using Arrhenius model. International Journal of Advanced Engineering and Management Research, 3(2), 85-94.

Adab, S.E., Wadda, W.B., Tekiki, A., Moussa, O.B., Boulares, M., Sadok, S. \& Hossouna, M. (2020). Effect of mixed starter cultures on biogenic amine formation during the ripening of Tunisian dry fermented camel meat sausage. Italian Journal of Food Science, 32(2), 321-336. DOI: 10.14674/IJFS-1733

Aksu, M.I. \& Kaya, M. (2004). Effect of usage Urtica dioica, L. on microbiological properties of sucuk, A Turkish dry-fermented Sausages. Food Control, 15, 591-595. DOI: 10.1016/j.foodcont.2003.09.006

Apaydın, G., Ceylan, Z.G., Kaya, M. (2009). The behaviour of E. coli 0:157:H7 in sucuk. Journal of Food Processing and Preservation, 33, 827-836. DOI: 10.1111/j.1745-4549.2008.00362.x

Arslan, A., Dincoglu, A.H. \& Gönülalan, Z. (2001). Gümüş balığından fermente sucuk üretimi üzerine deneysel çalışmalar. Kafkas Üniversitesi Veterinerlik Fakültesi Dergisi, 7, 47-54.

Arslan, B. \& Soyer, A. (2018). Effect of chitosan as a surface fungus inhibitor on microbiological, physicochemical, oxidative and sensory characteristics of dry fermented sausages. Meat Science, 145, 107-113. DOI:10.1016/j.meatsci.2018.06.012

Atik, A. (2013). Keçi etlerinin sucuk üretiminde değerlendirilmesi. Pamukkale Üniversitesi Fen Bilimleri Enstitüsü Yüksek lisans tezi. 85 sf. fermented fish sausages as well. In the study, both fermented fish sausages were determined as too much dried and exceeded the microbiological limit $(6.0 \mathrm{log} \mathrm{cfu} / \mathrm{g})$ of TMAB on the 90 th day of storage in the refrigerator at $6-8^{\circ} \mathrm{C}$. Moreover, the maximum level of the YM counts of dry fermented meat product was defined as microbiologically to be $2.00 \mathrm{log} \mathrm{cfu} / \mathrm{g}$ according to the Turkish Standards (2002). Therefore, fermented seabass sausage reached this limit on the $10^{\text {th }}$ day of storage, whereas fermented trout sausage reached this limit on the $30^{\text {th }}$ day of storage. As a result, it is suggested that fish sausages should be packaged in vacuum packaging because of preventing too much drying and the growth of undesirable moulds. Additionally, good hygienic qualified spices or natural compounds should also be used for preventing the growth of undesirable moulds on dry fermented fish sausages. Limited studies have been done about the production and determination of the qualities of dry fermented fish sausages. For this reason, much more studies should be advised to be done about dry fermented fish sausages. The studies should also be done about the identification of microorganisms of fermented fish sausages during storage period to determine desirable and undesirable microorganisms. The production, standardization and consumption of dry fermented fish sausage just like traditional dry fermented meat products in Turkey would be possible in the near future.

\section{ACKNOWLEDGEMENTS}

This study was supported by Ege University Scientific Research Projects Coordination Unit. Project Number: 10SÜF-014. It was presented as oral presentation at the II. International Fisheries Symposium IFSC 2018.
Berik, N. \& Kahraman, D. (2010). Determination of sensory and nutrient composition at mullet fish sausages. Kafkas Univ. Vet. Fak. Derg., 16 (Supl-A): S 59-S63. DOI: 10.9775/kvfd.2009.1376

Bou, R., Cofrades, S. \& Jimenez-Colmenero, F. (2017). Chapter 10: Fermented meat sausages. Fermented Foods in Health and Disease Prevention. 203-235. DOI: 10.1016/B978-0-12-802309-9.00010-8

Bozkurt, H. \& Erkmen, O. (2002). Effects of starter cultures and additives on the quality of Turkish style (sausages). Meat Science, 61, 149-156. DOI: 10.1016/s0309-1740(01)00176-0

Bozkurt, H. \& Bayram, M. (2006). Colour and textural attributes of sucuk during ripening. Meat Science, 73, 344- 350 DOI: 10.1016/j.meatsci.2006.01.001

Bozkurt, H. \& Erkmen, O. (2007). Effects of some commercial additives on the quality of sucuk (Turkish dry fermentented sausages). Food Chemistry, 101,1465-1473. DOI: 10.1016/j.foodchem.2006.04.002

Con, A.H. \& Gökalp, H.Y. (2000). Production of bacteriocin-like metabolites by lactic acid cultures isolated from sucuk samples. Meat Science, 55, 1, 89-96. DOI: 10.1016/S0309-1740(99)00129-1

Cruxen, C.E.S., Funck, G. D., Haubert, L., Dannenberg, G.S., Marques, J.L., Chaves, F.C., Silva, W.P. \& Fiorentini, A.M. (2019). Selection of native bacterial starter culture in the production of fermented meat sausages: Application potential, safety aspects and emerging Technologies. Food Research International, 122, 371-382. DOI: 10.1016/j.foodres.2019.04.018 
Cunha, L.C.M., Monteiro, M.L.G., Lorenzo, J.M., Munecato, M.E.S Muchenje, V., Carvalho, F.A.L. \& Conte Junior, C.A. (2018). Natural antioxidants in processing and storage stabilility of sheep and goat meat products. Food Research International, 111, 379-390. DOI: 10.1016/j.foodres.2018.05.041

Çoban, Ö.E. (2020). Production of fresh fish sausages containing natural preservatives (Laurus nobilis $L$.) it's nutritional composition and oxidative stability. Progress in Nutrition, 22 (2), 501-506 DOI: $10.23751 /$ pn.v22i2.8912

DeMan, J.C., Rogosa, M. \& Sharpe, M.E. (1960). A medium for cultivation of Lactobacilli, Journal of Applied Bacteriology, 23,130-135. DOI: 10.1111/j.1365-2672.1960.tb00188.x

Dinçer, M.T., Çaklı, Ş. \& Kılınç, B. (2007a). Fish sausages preparation from rainbow trout (Onchorhyncus mykiss) and quality changes during the refrigerator storage. 37 th WEFTA Meeting, Lizbon, Portekiz, October 24, 2007, p.64.

Dinçer, M.T., Çaklı, Ş. \& Kılınç, B. (2007b). Mezgit (Pollachius virens) filetolarından balık sosis üretimi ve soğuk muhafazada kimyasal ve mikrobiyal kalite kontrolü, 14. Ulusal Su Ürünleri Sempozyumu, 04 Eylül 2007, Muğla, Türkiye. sf.190.

Dinçer, M.T. \& Çaklı, Ş. (2015). Textural acceptability of prepared fish sausages by controlling textural indicators. Turkish Journal of Veterinary and Animal Sciences, 39, 364-368. DOI: 10.3906/vet-1307-38

Dinçer, M.T., YıImaz, E.B.Ş. \& Çaklı, Ş. (2017). Determination of quality changes of fish sausage produced from saithe (Pollachius virens L., 1758) during cold storage. Ege Journal of Fisheries \& Aquatic Sciences, 34(4), 391-399. DOI: 10.12714/egejfas.2017.34.4.05

Ekici, L., Ozturk, I., Kahraman, S. \& Calıkan, O. (2015). Effects of black carrot concentrate on some physicochemical, textural, bioactive, aroma and sensory properties of sucuk, a traditional Turkish dry-fermented sausages. LWT-Food Science and Technology, 62, 718-726. DOI: 10.1016/j.Iwt.2014.12.025

Ekici, K. \& Omer, A.K. (2018). The Determination of some biogenic amines in Turkish fermented sausages Consumed in Van, Toxicology Reports, 5, 639-643. DOI: 10.1016/j.toxrep.2018.05.008

Ercoşkun, H. (2006). Effects of fermentation time on some quality characteristics of heat processed sucuks. PhD. Dissertation. Graduate School of Natural and Applied Science. Ankara University, Ankara.

Eren, F. (2011). Gökkuşağı alabalığı (Onchorhyncus mykiss W., 1792)'ndan jambon yapımı ve raf ömrünün belirlenmesi. Süleyman Demirel Üniversitesi Fen Bilimleri Enstitüsü Su Ürünleri Avlama ve İşleme Teknolojisi ABD. Yüksek lisans Tezi, $59 \mathrm{~s}$.

Erkmen, O. \& Bozkurt, H. (2004). Quality characteristics of retailed sucuk (Turkish dry-fermented sausage). Food Technology and Biotechnology, $42,63-69$

Fernandez, M., Ordonez, J.A., Bruna, J.M., Herranz, B. \& Hoz, L. (2000). Accelerated ripening of dry fermented sausages. Trends in Food Science \& Technology, 11, 201-209 DOI: 10.1016/S0924-2244(00)00077-7

Gamgam, H. \& Altunkaynak, B. (2017). Parametrik Olmayan Yöntemler, 6. Baskı, Seçkin Yayıncııı.

Gonzalez-Mohino, A., Perez-Palacios, T., Antequera, T., Ruiz-Carrascal, J., Olegario, L.S., Grassi, S. (2020). Monitoring the processing of dryfermented sausages with a portable NIRS device. Foods, 9, 1294. DOI: $10.3390 / f o o d s 9091294$

Harrigan, W.F. \& McCance, M.E (1976). Laboratory Methods in Food Dairy Microbiology. London. Academic Press Inc.

Haouet, M.N., Altissimi, M.S., Mercuri, M.L., Baldassarri, C., Osimani, A., Clementi, F. \& Ortenzi, R. (2017). Evaluation of the safety of Milano-type dry fermented sausages produced by a fast drying technology. Italian Journal of Food Science, 29(3), 550-558.

Holck, A., Axelsson, L., McLeod, A., Rode, T.M. \& Heir, E. (2017). Health and safety considerations of fermented sausages. Journal of Food Quality. Article ID 9753894, 25 pages. DOI: 10.1155/2017/9753894
ICMSF (1983). Metodos, recomendados para el analisis microbiologico en alimentos, In: Microorganismos de los almentos. I. Tecnicas de analisis microbiologicos, 2da, Ed. Acribia, Zaragoza, Espana, 105-280.

Incze, K. (1998). Dry fermented sausages, Meat Science, 49, Supplement 1 , S169-S177. DOI: 10.1016/S0309-1740(98)90046-8

Kaya, M. \& Gökalp, H.Y. (2004). The behavior of Listeria monocytogenes in sucuks produced with diffrent lactic starter cultures. Turkish Journal of Veterinary and Animal Sciences, 28, 1113-1120.

Kaban, G. \& Kaya, M. (2006). Effect of starter culture on growth of $S$. aureus in sucuk. 2006. Food Control, 17, 797-801. DOI: 10.1016/j.foodcont.2005.05.003

Kaban, G. \& Kaya, M. (2009). Effects of Lactobacillus plantarum and Staphylococcus xylosus on the quality characteristics of dry-fermented sausage "sucuk". Journal of Food Science, 74, 58-63. DOI: 10.1111/j.1750-3841.2008.01014.x

Kara, R., Akkaya, L., Gok, V., Gürler, Z. \& Müdüroğlu, R. (2012). Farklı oranlarda manda eti kullanılarak üretilen sucukların olgunlaşma ve depolama aşamalarındaki bazı özelliklerinin araştıııması. Kocatepe Veterinary Journal, 5, 13-19.

Khem, S., Young, O.A., Robetson, J. \& Brooks, J.D. (2013). Development of model fermented fish sausages from marine species: a pilot physicochemical study. Food and Nutritional Sciences, 4 (12), 12291238. DOI: $10.4236 /$ fns. 2013.412157

KIlınç, B.(2003). Balık sos teknolojisi. E.Ü. Journal of Fisheries \& Aquatic Sciences, 20(1-2), 263-272.

KIIınç, B. (2004). Laktik asit fermentasyonu ile üretilen fermente su ürünleri. E.Ü. Journal of Fisheries \& Aquatic Sciences, 3(4), 371-374.

Kilınç, B., Cakli, S., Tolasa, S. \& Dinçer, M.T. (2006). Chemical, microbiological and sensory changes associated with fish sauce processing. European Food Research and Technology, 222, 604-613. DOI: 10.1007/s00217-005-0198-4

Kilınc, B. \& Sürengil, G. (2016). Microbiological changes in whiting (Merlangus merlangus Linneaus, 1758) fillets during short-term cold storage and a traditional 'pastrami-like' treatment. Journal of Applied Ichtyology, 32, 3, 548-551. DOI: 10.1111/jai.13043

Lonergan, S.M., Topel, D.G. \& Marple, D.N. (2019). Chapter 14: Sausage processing and production. The Science of Animal Growth and Meat Technology (Second Edition). 229-253. DOI: $10.1016 / B 978-0-12-815277-5.00014-7$

Lücke, F.K. (1985). Fermented sausages. In: Wood B.J.B. (Ed.), Microbiology of Fermented Foods. Elsevier Applied Science, New York.

Merck (1998). Gıda Mikrobiyolojisi, Orkim Kimyevi Maddeler Tic. Ltd. Şti. 168 $\mathrm{s}$.

Mossel, D.A. \& Moreno, G.B. (1985). Microbiologia de Alimentos, Acribia. Zaragoza. Espana, 214-272.

Nordvi, B., Egelandsdal, B., Langsrud, Q., Ofstad, R. \& Slinde, E. (2007). Development of a novel, fermented and dried saithe and salmon product. Innovative Food Science \& Emerging Technologies, 8, 163171. DOI: 10.1016/j.ifset.2006.09.002

Ordonez, J.A., Hierro, E.M., Bruna, J.M. \& Hoz, L. (2010). Changes in the components of dry-fermented sausages during ripening. Critical Reviews in Food Science and Nutrition, 39, 329-367. DOI: $10.1080 / 10408699991279204$

Öksüztepe, G., Güran, H.Ş., İncili, G.K. \& Gül, S.B. (2011). Elazığ'da tüketime sunulan fermente sucukların mikrobiyolojik ve kimyasal kalitesi. Firat Üniversitesi Sağlık Bilimleri Veterinerlik Dergisi, 25(3), 107-114.

Özpolat, E. (2012). Bazı tatı su balıklarından iki farklı tütsüleme yöntemiyle üretilen sosislerin raf ömrünün belirlenmesi. Fırat Üniversitesi Fen Bilimleri Enstitüsü Su Ürünleri Avlama ve Işleme Teknolojisi ABD. Doktora Tezi, $129 \mathrm{~s}$.

Papamanoli, E., Tzanetakis, N., Litopoulou-Tzanetaki, E. \& Kotzekidou, P. (2003). Characterization of lactic acid bacteria isolated from a Greek dry fermented sausage in respect of their technological and probiotic 
properties. Meat Science, 65, 859-867. DOI: 10.1016/S0309-1740(02)00292-9

Papavergou, E.J. (2011). Biogenic amine levels in dry fermented sausages produced and sold in Greece. Procedia Food Science, 1, 1126-1131. DOI: 10.1016/j.profoo.2011.09.168

Rantsiou, K. \& Cocolin, L. (2006). New developments in the study of the microbiota of naturally fermented sausages as determined by molecular methods: A review. International Journal of Food Microbiology, 108, 255-267. DOI: 10.1016/j.ijfoodmicro.2005.11.013

Scetar, M., Kovacic, E., Kurek, M. \& Galic, K. (2013). Shelf life of packaged sliced dry fermented sausage under different temperature. Meat Science, 93, 802-809. DOI: 10.1016/j.meatsci.2012.11.051

Sidira, M., Mitropoulou, G., Glanis, A., Kanellaki, M. \& Kourkoutas, Y. (2019). Effect of sugar content on quality characteristics and shelf-life of probiotic dry-fermented sausages produced by free or immobilized Lactobacillus casei ATCC 393. Foods, 8, 219. DOI: $10.3390 /$ foods 8060219

Stollewerk, K., Jofre, A., Comaposada, J., Arnau, J. \& Garriga, M. (2014). Food safety and microbiological quality aspects of QDS process and high pressure treatment of fermented fish sausages. Food Control, 38, 130-135. DOI: 10.1016/j.foodcont.2013.10.009

Sun, Q., Zhao, X., Chen, H., Zhang, C. \& Kong, B. (2018). Impact of spice extract on the formation of bigenic amines and the physicochemical, microbiological and sensory quality of dry sausage. Food Control, 92, 190-200. DOI: 10.1016/j.foodcont.2018.05.002
Suzzi, G. \& Gardini, F. (2003). Biogenic amines in dry fermented sausages: A review. International Journal of Food Microbiology, 88, 41-54. DOI: 10.1016/S0168-1605(03)00080-1

TSE. (2002). Turkish Standard Enstitute. Turkish sucuk. Turkish standard. TS1070, ICS 67.120.10. Ankara.

Ünlütürk, A. \& Turantaş, F. (2003). Gıda Mikrobiyolojisi. META Basım Matbaacılık Hizmetleri, ISBN: 975-483-383-4.

Vanderzant, C. \& Splittstoesser, D.F. (1992). Compendium of Methods for the Microbiological Examination of Foods. 3rd Edition, American Public Health Association, Washington DC, 423-431.

Vignolo, G., Fontana, C. \& Fadda, S. (2010). Semidry and dry fermented sausages. Chapter 22 Handbook of Meat Processing.

Wang, W., Xia, W., Gao, P., Xu, Y.\& Jiang, Q. (2017). Proteolysis during fermentation of Suanya as a traditional fermented fish product of China. International Journal of Food Properties, 20:sup1, S166-S176. DOI: 10.1080/10942912.2017.1293089

Yaman, A., Gökalp, H.Y. \& Con, A.H. (1998). Some characteristics of lactic acid bacteria present in commercial sucuk samples. Meat Science, 49, 387-397. DOI: 10.1016/S0309-1740(98)00004-7

Yılmaz, D.K. \& Berik, N. (2013). Quality determination of experimental sausage production from shark meat. Marine Science and Technology Bulletin, 2(2), 1-4.

Yoo, S.A., Park, S.E., Seo, S.H. \& Son, H.S. (2016). Quality characteristics of fermented sausage prepared with soy sauce. Food Science and Biotechnology, 25, 533-539. DOI: 10.1007/s10068-016-0074-y 